\title{
FRA-JCOPEデータに基づく東シナ海周辺海域の流動特性の解析

\author{
FRA-JCOPE data analysis for long-term variation of coastal ocean current characteristics \\ in the East China Sea
}

\author{
山下隆男 ${ }^{1} \cdot$ Hendri $^{2} \cdot$ 永山大地 $^{3}$ \\ Takao YAMASHITA, HENDRI and Daichi NAGAYAMA
}

\begin{abstract}
Coastal ocean current fields of the surrounding waters in the East China Sea continental shelf are affected not only by the climate change and Kuroshio current, but also by the large river-oriented fresh waters, such as the Changjiang diluted water (CDW) and the Yellow Sea mixed water (YSMW), which are strongly affected by land use, land cover and human activities. In this study, the monthly variation of flow discharges of Kuroshio, CDW, YSMW and Taiwan Strait coastal waters was analyzed for the 19 years (January 1993 to September 2011) using the re-analysis data of ocean currents FRA-JCOPE to investigate the long-term variation of flow properties in the East China Sea. The analysis made clear that Kuroshio off the Taiwan coast is on the increase of $0.2453 \mathrm{~Sv} / \mathrm{yr}$ and $0.00239 \mathrm{~Sv} / \mathrm{yr}$ for Taiwan strait current.
\end{abstract}

\section{1. 緒 言}

日中韓の経済水域を含む東シナ海の大陸棚は，世界有 数の漁獲生産量を誇る海域であり, 水産資源やその基礎 となる生態系保全は当事国のみならず国際的にも関心が 高い.この大陸棚の流動場・水質は気候変動と黒潮の影 響以外にも, 長江起源水, 黄河混合水の流量変動等, 人 間活動に起因する河川水の水質や拡散過程によっても大 きな影響を受ける。本研究ではFRA-JCOPE（Japan Coastal Ocean Predictability Experiment) の海洋再解析デー 夕（Miyazawa et al, 2009，宮澤 2005）を用いて1993年か ら 2011 年 9 月までの 18 年 9 ケ月間の流速の3次元分布の 月別変化を解析し, 東シナ海海域における流動特性の長 期変動特性を検討する。

\section{FRA-JCOPEプロジェクトの概要}

海洋変動予測実験FRA-JCOPEの北西太平洋高解像度 モデル（水平 $1 / 12$ 度，45層）の解析結果を用いた。この 解析では, プリンストン海洋モデル $\mathrm{POM} / \mathrm{POMgcm}$ を改 良したプログラムコードが使用されている。衛星海表面 水温, 衛星海面高度, 船舶観測水温・塩分の重み付け多 変数最適内挿法によるデータ同化が用いられている. 3.5 日間モデルで予測した後に，その予測值と解析值の差を 7 日間で緩和する強制力を 7 日間与えた状態で再度モデ ルを計算するという方法が取られている，外力としては

\begin{tabular}{lll}
\hline 正会員 工博 & $\begin{array}{l}\text { 広島大学教授 大学院国際協力研究科開 } \\
2 \text { 正会員 工科学専攻 }\end{array}$ \\
& & $\begin{array}{l}\text { 広島大学特任助 大学院国際協力研究 } \\
\text { 科開発科学専攻 } \\
\text { 九州大学大学院 総合理工学府大気海洋 } \\
\text { 環境システム学専攻 }\end{array}$
\end{tabular}

準リアルタイムに取得可能な現実的な風応力 (QuickSCAT NRT), 熱フラックス（NCEP/NCAR 客観解 析 6 時間平均值）で駆動し，塩分は気候值で緩和してい る (Miyazawa et al, 2010). 再解析データには, 水温, 塩 分, 流速分布データがあるが, 本解析では流速（鉛直積 分流量を算定）の長期変動を対象とした.

\section{3. 東シナ海での流れの構造}

図-1に対象とした東シナ海周辺海域の海底地形を示 す. 北から南へ大隅諸島, トカラ列島, 奄美群島, 沖縄 諸島, 宮古列島, 八重山列島, 尖閣諸島, 大東諸島で形 成される南西諸島に繋がり，沖縄トラフ上を東シナ海の 大陸棚に沿って流れる黒潮が太平洋に流路転向する海域 である.さらに，フィリピン海プレートがユーラシア大 陸プレートに潜り达む琉球トレンチでは巨大地震とそれ による津波が矁念される海域でもある.

東シナ海には複数の水塊が存在する. それら主なもの として台湾海峡沿岸水, 黒潮表層水 (黒潮), 黒潮亜表 層水 (黑潮), 黄海混合水, 対馬海流, および長江起源

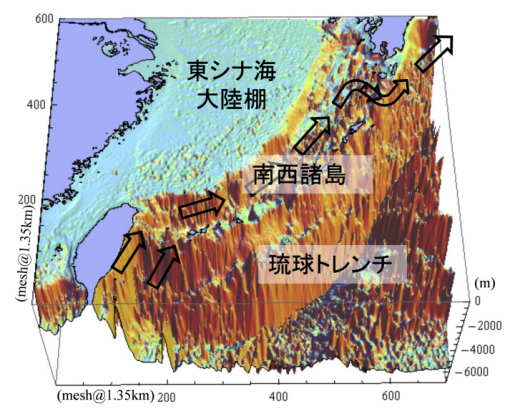

図-1 対象海域の海底地形 


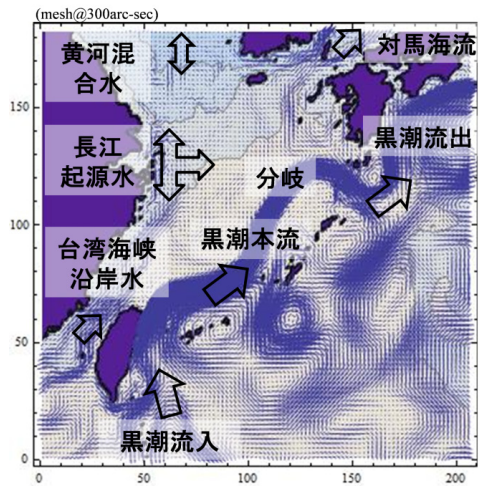

図-2 解析対象とした東シナ海の水塊流動

水等に分類される. 本研究では図-2に示す水塊を対象と する.

解析対象とした水塊の特性の概要は以下のようである. 台湾海峡沿岸水：台湾海峡を通過した流れは陸棚上を北 上する. 台湾北東で陸棚域に進入する黒潮の一部との連 続性が考えられる，黑潮より若干低塩分・低酸素の特徵 を持った水塊である。この流れは夏季に長江起源水が南 の方には拡がらない要因にもなっていると考光られる. また，この水塊は栄養塩を豊富に含んでいる．これは大 都市香港の開発や, フィリピン, 台湾沿岸の工業都市な どの経済活動の影響である。ささらに, 台湾北部海域は黒 潮の湧昇域であり, 深層から供給される栄養塩の存在も 重要である.中国長江流域の開発は著しく, 長江への栄 養塩類の負荷は莫大で, さらに増大する傾向にある.

海域へのこうした高濃度の栄養塩を含む淡水供給は長 江河口域を含む東シナ海沿岸の生態系に影響を及ほし, 実際，赤潮発生頻度は1980年代から 1990 年代までに 4 倍増加するに至っている. さらに1995年以降では, 東シ ナ海沿岸域における赤潮形成種が珪藻から渦鞭毛藻へと 遷移する傾向が報告されており, 長江流域の開発が海洋 生態系に変化をもたらしている可能性が示唆される.

長江起源水：長江から流入した河川水は周辺の海水と混 合することによって徐々に塩分が高くなり長江希釈水と して陸棚域に拡がっている. 長江からの水塊は流量が大 きいため, その影響は東シナ海陸棚域に留まらず, 対馬 海峡でも明瞭な影響が見られ, 大半は日本海に流入して いると考えられている. 冬季には北寄りの季節風の影響 で長江からの河川水は中国沿岸に沿って南に流れ, 中国 沿岸流として台湾海峡まで達する，長江起源の豊富な栄 養塩を含む淡水の流入は我が国の排他的経済水域を含む 東シナ海陸棚域における藻類一次生産を基礎とする生物 資源の維持, 海洋環境の形成に深く関与している.

対馬海流: 対馬海峡を通過した黑潮の一部が対馬海流と して日本海に輸送されている。この海流は黒潮と台湾海
峡沿岸水の影響を受けている. 夏季には長江起源水の拡 散, 冬季には季節風の影響を受けやすい台湾海峡沿岸水 の影響を受ける。

黄海混合水：以下の 5 水塊で構成される。i）黄河暖流水 は暖かく高塩分で, 済州島の西から北西に冬季にフロン 卜を形成する. ii）黄海底層冷水は冬季の混合によるも のである. iii）韓国沿岸水は朝鮮半島から流入する表層 水と河川水が潮汐によって海水と混合したものである. iv）中国沿岸水は渤海からの流入水を含み年間を通じて 南下する。v）長江希釈水は太平洋の縁海域で最も塩分 が低い水塊である。

\section{4.データ解析方法}

FRA-JCOPEの再解析結果は, 空間刻み $300 \operatorname{arcsec}$ の日 平均デー夕である. 解析の対象海域では水平格子数 (206，182), 鉛直45層の3 次元流速デー夕となる. 海流 の時間スケールの長さを考慮して各月の第 1 日のデータ をその月の代表值とし，1993年1月から2011年9月まで の約 19年間を解析した. 図-3に $\sigma$ 座標系での流速の3 次 元分布の一例を示す，流量は図-4の左に示すように, 各 層の流速と断面積を掛けて鉛直積分し, 単位 $\mathrm{Sv}\left(10^{6} \mathrm{~m}^{3} / \mathrm{s}\right)$ で表示した。デー夕解析にはMathematicaを使用した.

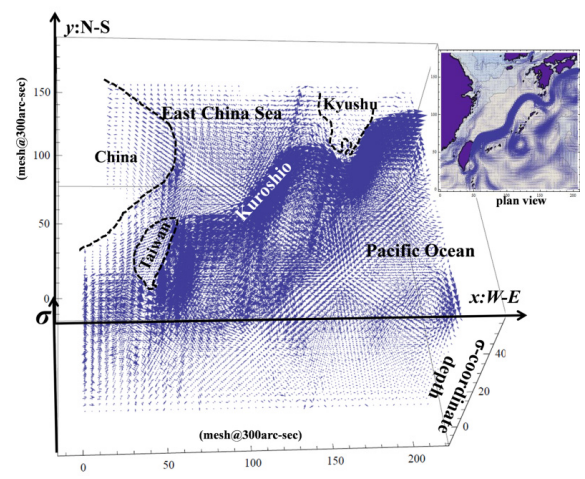

図-3 $\sigma$ 座標系での流速データの 3 次元場の表示例

本研究では, 図-2に設定した東シナ海の流れの分類に 従って, それらの流量変動を解析するため, 以下の 8 検 查断面を設定する。(1)黑潮流出（黑潮 OUT), (2)黑潮流 入 (黒潮 $\mathrm{IN}$ ), (3)対馬海流, (4)台湾海峡沿岸水, (5)黄海 混合水 (北からの流入が正), (6)長江起源水沖方向流 River Mouth (沖方向が正), (7)長江起源水北流 North（北 向きが正), 8長江起源水南流 South（南向きが正). 表-1 に検査断面両端部の緯度, 経度を示す.

\section{5. 解析結果}

図-5〜9に，各検查断面を通過する約 19年間（18.75年） の断面流量の時間変動（上図）と線形回帰式によるトレ 

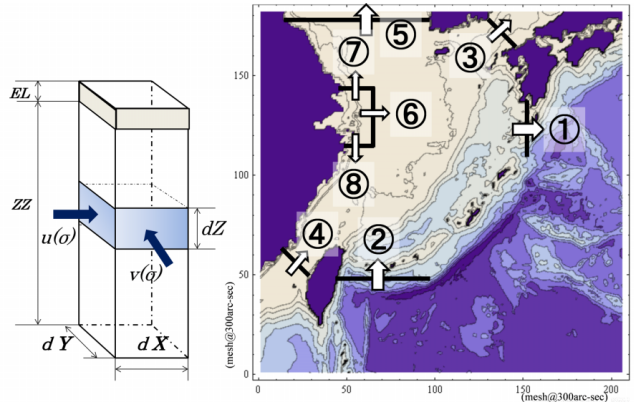

図-4 $\sigma$ 座標系 (45 層) 鉛直断面の概念図と流量解析検查断面

表-1 検査断面の位置

\begin{tabular}{l|c|c|c|c}
\hline & \multicolumn{2}{|c|}{ 東経 } & \multicolumn{2}{c}{ 北緯 } \\
\hline (7)長江起源水 N & $122.583^{\circ}$ & $123.750^{\circ}$ & \multicolumn{2}{|c}{$31.583^{\circ}$} \\
\hline (6)長江起源水 RM & \multicolumn{2}{|c|}{$123.750^{\circ}$} & $29.083^{\circ}$ & $31.583^{\circ}$ \\
\hline (8)長江起源水 S & $122.583^{\circ}$ & $123.750^{\circ}$ & \multicolumn{2}{|c|}{$29.083^{\circ}$} \\
\hline (4)台湾海峡沿岸水 & $118.917^{\circ}$ & $119.917^{\circ}$ & $24.167^{\circ}$ & $25.167^{\circ}$ \\
\hline (2)黑潮 IN & $122.167^{\circ}$ & $125.750^{\circ}$ & \multicolumn{2}{|c|}{$24.167^{\circ}$} \\
\hline (1)黑潮 OUT & \multicolumn{2}{|c|}{$130.417^{\circ}$} & $29.083^{\circ}$ & $31.250^{\circ}$ \\
\hline (3)対馬海流 & $128.500^{\circ}$ & $129.667^{\circ}$ & $33.500^{\circ}$ & $34.583^{\circ}$ \\
\hline (5)黄海混合水 & $119.834^{\circ}$ & $126.084^{\circ}$ & \multicolumn{2}{|c|}{$34.583^{\circ}$} \\
\hline
\end{tabular}

表-2 19年間の流量変化の回帰式

\begin{tabular}{l|c|c|c}
\hline \multicolumn{1}{c|}{ 対象地域 } & 直線式 & 19 年増減 & 年平均増減 \\
\hline (7)長江起源水 $\mathrm{N}$ & $\mathrm{y}=2 \mathrm{E}-05 \mathrm{x}-0.0096$ & +0.00448 & +0.00023893 \\
\hline (6)長江起源水 $\mathrm{RM}$ & $\mathrm{y}=1 \mathrm{E}-05 \mathrm{x}-0.1364$ & +0.00224 & +0.00011947 \\
\hline (8)長江起源水 $\mathrm{S}$ & $\mathrm{y}=-0.0001 \mathrm{x}+0.041$ & -0.0224 & -0.001195 \\
\hline (4)台湾海峡沿岸水 & $\mathrm{y}=0.0002 \mathrm{x}+0.9204$ & +0.04484 & +0.00238933 \\
\hline (2)黒潮 IN & $\mathrm{y}=0.0208 \mathrm{x}+28.955$ & +4.6592 & +0.24849067 \\
\hline (1)黑潮 OUT & $\mathrm{y}=-0.0008 \mathrm{x}+35.814$ & -0.1792 & -0.00955733 \\
\hline (3)対馬海流 & $\mathrm{y}=3 \mathrm{E}-06 \mathrm{x}+2.231$ & +0.000672 & +0.00003584 \\
\hline (5)黄海混合水 & $\mathrm{y}=0.0004 \mathrm{x}-0.0613$ & +0.0896 & +0.0047786 \\
\hline
\end{tabular}

ンド（図 (a) の濃い破線）, 季節・経年変動（下図. 図 中のEはEl Nino，LはLa Nina発生時. 図-10参照）を示 す。また，表-2に線形回帰式の結果をまとめた。

\section{（1）黒潮の流入，流出特性}

断面(2)を通過する流量は台湾の東側から南西諸島の西 側に流入する黒潮である（黒潮 IN）。また，断面(1)を通 過する流量は対馬海流への分岐後，南西諸島から流出す る黒潮である（黒潮OUT）。図-5に流入流出の流量の変 化と黒潮 INの季節変動を示す。考察を以下にまとめる.

（1）黑潮流入量はENSO と連動しており，El Ninoから La Nina移行期に突発的な増加（約 70〜80Svに至る） が見られる。長期トレンドは年々上昇傾向にあり， 約 19 年間で $4.66 \mathrm{~Sv}$ の流量増加がある. 地球温暖化と

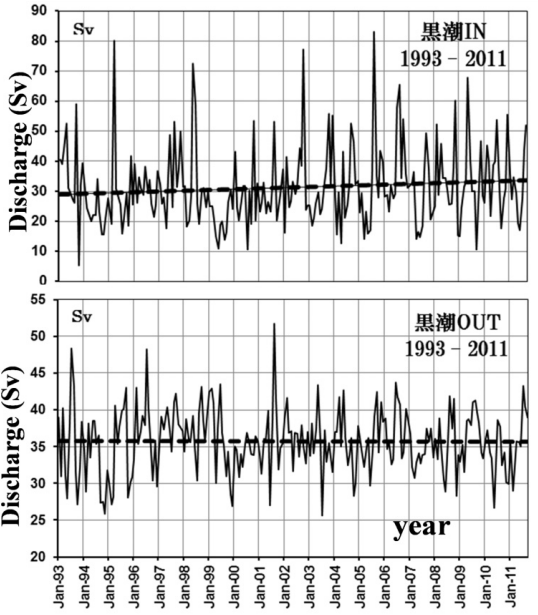

(a) 流量の経年変化

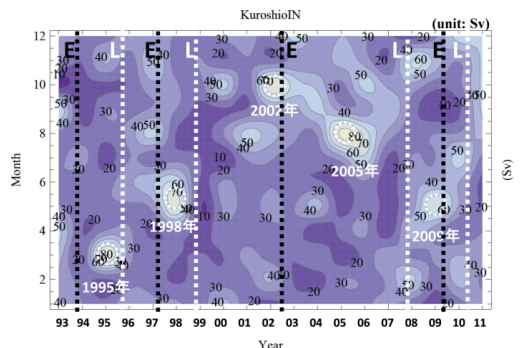

（b）流量の季節変化（E: El Nino，L: La Nina 発生時） 図-5 黒潮流入，流出の流量変動

関連していると考えられる。また，台湾海峡沿岸水 も黑潮流入量と連動しており約 19 年間で 0.0448 Sv増 加している.

（2）黒潮流出（OUT）は季節風の影響な少なく，長期変 動も小さい．流量の変動は30〜 40Svで流路も安定 している.

\section{（2）長江起源水の流動特性}

長江起源水の (7)北流 (North), 8)南流（South），6沖 流出流（River Mouth）の流量変動と沖流出成分の季節 · 経年変動を図-6に示す。これらより以下の事がわかる.

（1）夏季に長江からの流出が卓越し，冬季には弱まる.

（2）冬期季節風で南流成分は強化されるが，逆流である 台湾海峡沿岸水が強い場合には弱まる。南流成分は 約 19 年間で $0.0224 \mathrm{~Sv}$ が減少し，台湾海峡沿岸水は $0.0448 \mathrm{~Sv}$ 増加している。合計では台湾海峡を北流成 分は増加.

（3）沖流出流は $0.00224 \mathrm{~Sv}$ ，北流は 0.00448Sv増加してい るが，長江起源水全体としては，0.01568Sv減少し ており，これは長江流域の三峡ダム建設や流域の 経済活動等，人為的影響を受けているものと考え られる。 


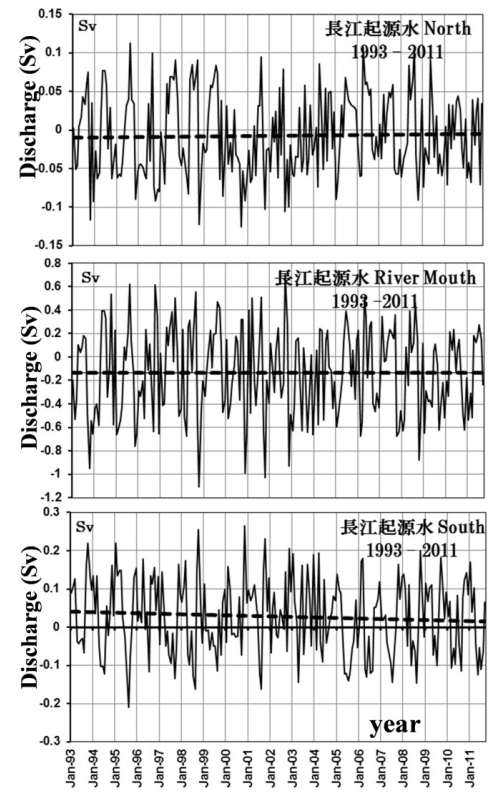

(a) 流量の経年変化

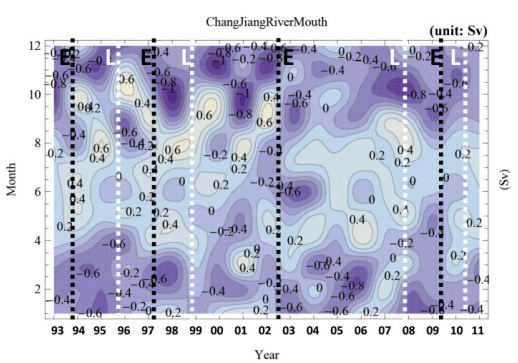

（b）流量の季節変化（E: El Nino, L: La Nina 発生時）

図-6 長江起源水の流量変動

（3）台湾海峡沿岸水, 黄河混合水, 対馬海流の特性

図-7〜9から, 台湾海峡沿岸水, 黄河混合水, 対馬海 流の特性として, 以下の事が考察される.

（1）台湾海峡沿岸水：夏季に流量は増加し冬季に減少す るが極めて安定に流れ, 約 $0.95 \mathrm{~Sv}$ の平均流量で北上 する. 冬季に南下する長江起源水の南流成分と相互 作用する. 年平均約 $0.00239 \mathrm{~Sv}$ の増加傾向にある.

（2）黄海混合水：黄河, 渤海, 朝鮮半島からの流入淡水 の流動で, 季節風および降雨量の影響が顕著である. 冬季には南下（負）し, 夏季には北上（正）する季 節変動がある，流量収支はほぼゼロであるが，年平 均で $0.00478 \mathrm{~Sv}$ の増加傾向にある。これは，黄河の 断流や渤海周辺の人的な活動で淡水の流出量が減つ ていることを意味する。

（3）対馬海流：黑潮分岐流と黄河混合水の影響を受ける. 流量は年間を通して安定しており平均的に $2.2 \mathrm{~Sv}$ 程 度で長期変化は少ない. 秋に流量が増加し春先に減

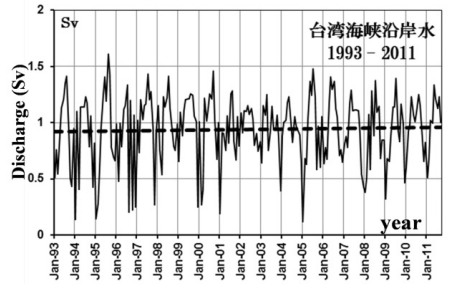

(a) 流量の経年変化

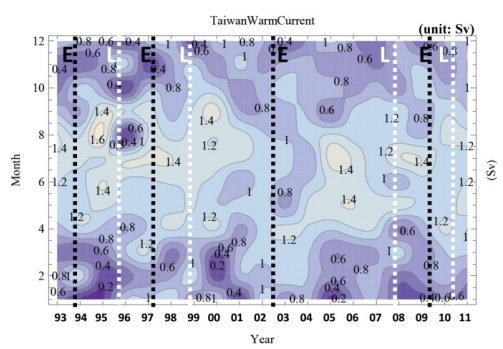

（b）流量の季節変化（E: El Nino, L: La Nina 発生時） 図-7 台湾海峡沿岸水の流量変動

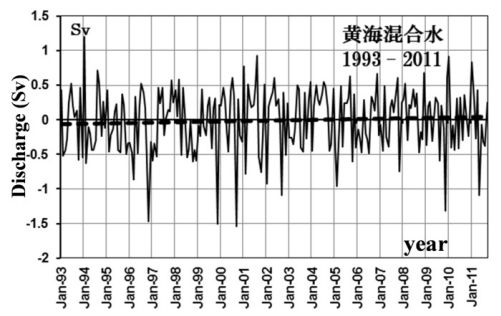

(a) 流量の経年変化

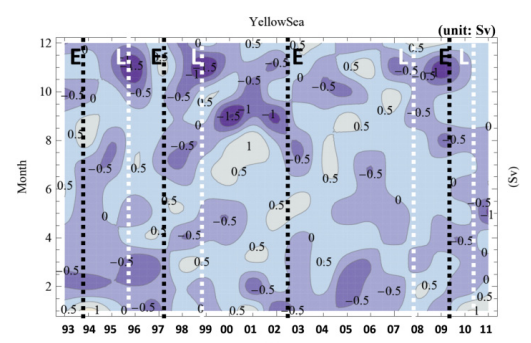

（b）流量の季節変化（E: El Nino, L: La Nina 発生時)

図-8 黄河混合水の流量変動

少する。

（4）La Ninaの冬季に黄海混合水の流入（南下）が強 まる。

（4）海流の長期変動と太平洋海洋振動

黒潮流入量はENSO と連動しており, E1 Nino $\Leftrightarrow$ La Nina移行期に突発的な増加が見られる. 図-10 (a) にMEI （Multivariate ENSO Index，Wolter \& Timlin, 1998）と黒潮 流入量との関係を示す。（b）にはMEIの季節・経年変動 を示す。 


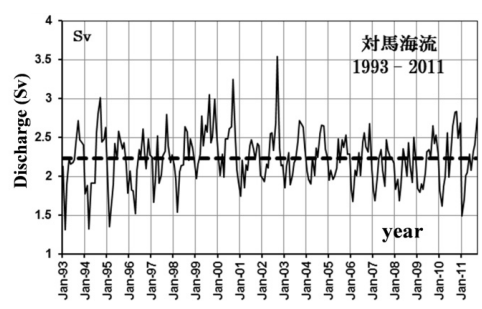

(a) 流量の経年変化

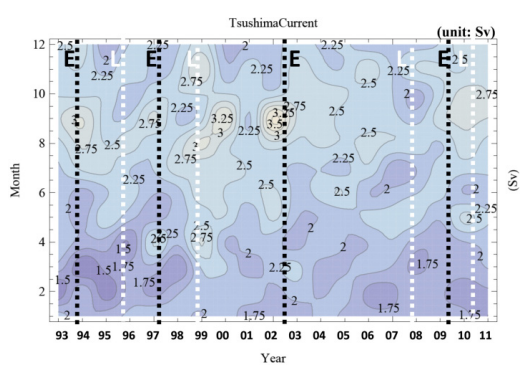

（b）流量の季節変化（E: El Nino， L: La Nina 発生時）

図-9 対馬海流の流量変動

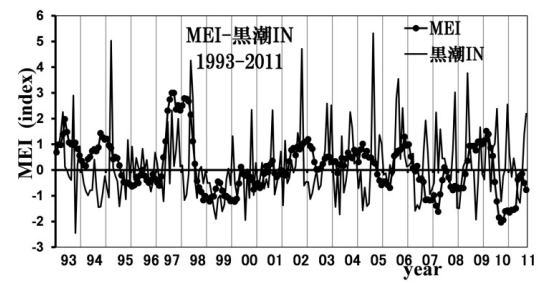

(a) MEI 指数の経年変化

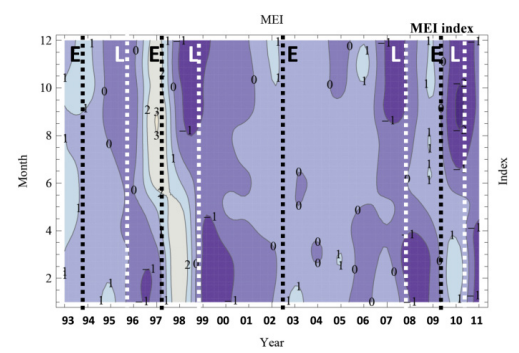

(b) MEI 指数の季節変化

図-10 海流の長期変動と太平洋海洋振動

El Nino時（MEIが正）に文字E，La Nina発生時（MEI が負）に文字Lを付した破線を入れている.

文字E，LはENSO と流動特性との関係を調べるため, 図-5９9 下図 (b) にも入れてある. 解析した水塊流動 でENSO との相関がみられたのは，台湾東岸の黑潮流入 量がE1 Nino $\Leftrightarrow$ La Nina移行期に突発的な増加があるこ と, La Ninaの冬季に黄海混合水の流入強化（河川からの
流出増加に起因）する現象であった。これら以外には， 流量変動と ENSO との間には顕著な関係は見いだせなか った.

\section{6. 結 語}

FRA-JCOPEの海洋再解析デー夕を用いて東シナ海海域 に打ける設定水塊の通過断面流量の長期変動特性を検討 した結果，以下のよう成果を得た。

1）黑潮流入量はENSOと連動しており, El Ninoから La Nina移行期に突発的な増加が見られる。約 19年間で $4.66 \mathrm{~Sv} \quad(0.2453 \mathrm{~Sv} / \mathrm{yr})$ の流量増加がある. 地球温暖 化と関連していると考えられる。

2）黑潮流出（OUT）：季節風の影響な少なく，長期変 動も小さい，流路抢よび流量は極めて安定している.

3）夏季に長江からの流出が卓越し，冬季には弱まる. 冬の季節風で南流成分は強化されるが，逆流である 台湾海峡沿岸水が強い場合は弱まる。沖流出流は $0.00224 \mathrm{~Sv}$, 北流は $0.00448 \mathrm{~Sv}$ 増加しているが, 長江起 源水全体としては，0.01568Sv減少しており，これは 長江流域の三峡ダム建設や流域の経済活動等, 人為 的影響を受けているものと考えられる.

4）台湾海峡沿岸水：夏季に流量は増加し冬季に減少す る。約 $0.95 \mathrm{~Sv}$ の平均流量で北上する安定な流れ。冬 季に南下する長江起源水の南流成分と相互作用する. 年平均で約 $0.00239 \mathrm{~Sv}$ の増加傾向にある.

5）対馬海流：年間を通して安定し，平均的に $2.2 \mathrm{~Sv}$ 程度 で長期変化は少ない。秋に流量が増加し春先に減少 する.

6）黄海混合水：年平均で $0.00478 \mathrm{~Sv}$ の増加傾向にある. これは, 黄河の断流や渤海周辺の人的な活動で淡水 の流出量が減っていることを意味する.

\section{参 考 文 献}

Miyazawa, Y., R. Zhang, X. Guo, H. Tamura, D. Ambe, J.-S. Lee, A. Okuno, H. Yoshinari, T. Setou, and K. Komatsu (2009) :Water mass variability in the western North Pacific detected in a 15year eddy resolving ocean reanalysis, J. Oceanogr. 65, pp.737756.

Miyazawa, Y., X. Guo, R. Zhang, S. M. Varlamov, T. Watanabe, T. Setou, and, D. Ambe (2010) : Roles of the in-situ observations in the detection of the Kuroshio frontal variability south of Japan, 2010 Ocean Sciences Meeting P035M-10.

Wolter, K., and M. S. Timlin, (1998) : Measuring the strength of ENSO events - how does 1997/98 rank?, Weather, 53, pp.315324.

宮澤泰正（2005）:JCOPE海洋変動予測システム使用の手引き $107 \mathrm{p}$. 